\title{
Analysis of Whole Cell Protein Profiles by SDS-PAGE to Identify Indigenous Cellulose-producer Acetic Acid Bacteria
}

\author{
Sarkono $^{1,}$, Sukarti Moeljopawiro ${ }^{2}$, Bambang Setiaji ${ }^{3}$, Langkah Sembiring ${ }^{2}$ \\ ${ }^{1}$ Department of Biology, Faculty of Mathematics and Natural Sciece, Mataram University, \\ Mataram, Indonesia \\ ${ }^{2}$ Faculty of Biology, Universitas Gadjah Mada, Jalan Teknika Selatan, Sekip Utara, \\ Yogyakarta 55281, Indonesia \\ ${ }^{3}$ Department of Chemistry, Faculty of Mathematics and Natural Sciences, \\ Universitas Gadjah Mada, Yogyakarta, Indonesia
}

\begin{abstract}
This study was carried out to analyze the suitability of the identification of four indigenous celluloseproducing acetic acid bacterial isolates (ANG29, KRE65, ANG32 and SAL53) based on the analysis of whole cellular protein profiles against identification based on phenotypic traits. Whole cellular protein profiles were determined by sodium dodecyl sulfate-polyacrylamide gel electrophoresis (SDS-PAGE) method. The whole cellular protein profiles obtained from sample isolates, were compared with reference isolates for species identification. The results showed that based on visual observations can be determined as much as 12 bands of protein with a molecular weight of 19,099 KDa up to $132.182 \mathrm{KDa}$. Based on the analysis of protein bands were detected visually, fourth indigenous cellulose- producing acetic acid bacterial isolates in the study had a higher similarity profile to the reference strain Gluconacetobacter xylinus BTCC 769 compared with other reference strains namely G. hansenii NBRC $14820^{\mathrm{T}}$. This condition is consistent with the results of the identification of fourth cellulose producing acetic acid bacterial isolates based on phenotypic traits. Thus, the whole cellular protein profiles by SDS-PAGE technique can be used as a one of method to identification of cellulose producing acetic acid bacterial isolates.
\end{abstract}

Keywords: Acetic acid bacteria, bacterial cellulose, identification, SDS-PAGE, whole cellular protein

\section{Introduction}

Acetic acid bacteria $(\mathrm{AAB})$ is a group of bacteria with common characteristics have the ability to oxidize alcohol and sugar, especially oxidize ethanol to acetic acid and have been widely used in the commercial industry such as the production of acetic acid, gluconate, sorbose (Jojima et al., 2004), and cellulose (Swissa et al., 1980). This bacterial group indicates the Gram negative reactions, ellipsoid to rod cells and some of its members have the ability to produce extracellular cellulose (Hanmoungjai et al., 2007). Acetic acid bacteria are known to have good adaptability on liquids that contain lots of

\footnotetext{
*Corresponding author:

Sarkono

Department of Biology, Faculty of Mathematics and Natural Sciences, Mataram University, Mataram, Indonesia

E-mail: sarkonobiologi@unram.ac.id
}

sugar and alcohol (Jojima et al., 2004), so that the main habitat in nature which include acetic acid, ripe fruits, liquid latex plants, alcoholic drinks and flowers.

Several studies have been conducted to isolate Gluconacetobacter of fruits (Kojima et al., 1998; Dellaglio et al., 2005), flowers, food fermentations (Lisdiyanti et al., 2001; Park et al., 2003), drinks (Jia et al., 2004; Kadere et al., 2008), and vinegar (Sokollek et al., 1998; Son et al., 2002; Hwan et al., 2004). Although some other types of bacteria such as Agrobacterium, Pseudomonas, Rhizobium, and Sarcina have the ability to produce cellulose, Gluconacetobacter is known as cellulose-producing bacteria with the highest capability (Jonas and Farah, 1998; Klemm et al., 2005).

Systematically, acetic acid bacteria are classified into Acetobacteraceae family as one evolutionary line branching subclasses of aProteobacteria (De Ley et al., 1984; Sievers et 
al., 1994). At first, acetic acid bacteria were classified into three genera, namely Gluconobacter, Acetobacter, and Fratueria (Holt et al., 1994). Currently, Acetobacteraceae family consists of 10 genera (Muramatsu et al., 2009), namely Acetobacter, Acidomonas, Asaia, Gluconacetobacter, Gluconobacter, Granulibacter, Kozakia, Neoasaia, Saccharibacter, and Swaminathania. The latest genus found is Granulibacter (Greenberg et al., 2006), which is the only member of the Acetobacteraceae family that is pathogenic.

Sodium Dodecyl Sulphate Poliacrylamide Gel Electrophoresis (SDSPAGE) protein pattern analysis has been successfully used to identify various types of bacteria, including Listeria species (Park et al., 2006), lactic acid bacteria (Ghazi et al., 2009), Salmonella serovars (Aksakal, 2010), and to solve problems in the identification of closely related species in the genera Lactobacillus and Leuconostoc (Dicks et al., 1990; Pot et al., 1993; Kim et al., 2003; Sanchez et al., 2003; Jin et al., 2008). However, the usefulness of this method for the identification of cellulose producing acetic acid bacteria strains isolated from ripe fruits and nata inoculum has not yet been assessed. In this article, we screened and identified acetic acid bacteria strains using SDS-PAGE of whole-cell proteins. The objective of this study was to analyze the suitability of identification of four indigenous cellulose producing acetic acid bacterial strain (ANG29, KRE65, ANG32 and SAL53) based on the analysis of total cellular protein profiles againts identification based on phenotypic traits.

\section{Materials and Methods}

\section{Acetic acid bacteria strains}

Four strains indigenous celluloseproducing acetic acid bacteria used in this study namely ANG29, KRE65, ANG32 and SAL53 were potentially cellulose producing strains isolated from ripe fruits and Nata de Coco inoculum. The reference strains used in this research were Gluconacetobacter hansenii NBRC $14820^{\mathrm{T}}$ obtained from NITE Biological Rensource Center (NBRC) Japan and Gluconacetobacter xylinus BTCC 769 obtain from Biotechnology Culture Collection (BTCC) LIPI Cibinong, Indonesia.

\section{Extraction of total proteins}

Identification of four selected strains with a chemosystematic approach is based on the protein finger printing. Proteins were analyzed in the dissolved form and whole cell proteins were visualized using SDS-PAGE. Furthermore, whole protein fingerprint profiles were obtained from all selected strains and reference strains analyzed numerically to determine the value of similarity.

Cell protein extraction and electrophoresis were carried out by modification of the procedure developed by Scopes (1987) and Aksakal (2010). Four strains indigenous cellulose-producing acetic acid bacteria (ANG29, KRE65, ANG32 and SAL53) and two reference strains (G. xylinus 769 BTCC and G. hansenii NBRC 14820T) each was grown in $100 \mathrm{ml}$ of Hestrin-Schramm (HS) medium and then incubated aerobically in a shaker incubator at $100 \mathrm{rpm}, 30^{\circ} \mathrm{C}$ for 72 hours. Suspension cultures of each bacteria centrifuged at $15,000 \mathrm{rpm}, 4^{\circ} \mathrm{C}$ for 15 minutes. Cell pellets were suspended in $10 \mathrm{ml}$ of buffer solution of $0.1 \mathrm{M}$ phosphate buffer saline $\mathrm{pH}$ 7.4. One $\mathrm{ml}$ suspension transferred to a 1.5 $\mathrm{ml}$ microsentrifuge tube and centrifuged at $15,000 \mathrm{rpm}$ for $15 \mathrm{~min}$ at $4^{\circ} \mathrm{C}$. The precipitate entrained resuspended in $10 \mathrm{~mL}$ solution of $10 \%$ SDS and $10 \mathrm{~mL}$ of loading buffer solution [0,125M Tris (hydroxymethyl) aminomethane, 4\% SDS, $10 \% \quad 2-$ mercaptoethanol, $0.2 \%$ Bromophenol blue; $\mathrm{pH}$ 6.8]. The mixture was then homogenized with a vortex, then the sample was boiled for 10 minutes at $100^{\circ} \mathrm{C}$, centrifuged for 1 minute $\left(15,000 \mathrm{rpm}\right.$ at $\left.20^{\circ} \mathrm{C}\right)$. Supernatant obtained was taken and used as a protein sample. The protein content of the sample was measured by the method of Bradford (Bradford, 1976) using Bio-rad protein assay.

\section{Electrophoresis}

Samples of protein (supernatant) as much as $30 \mathrm{~mL}$ was added on to electrophoresis loading buffer $5 \mathrm{X}(6 \mathrm{~mL})$ and then incubated at a temperature of $100^{\circ} \mathrm{C}$ for 2 minutes and as soon as may be stored at $0^{\circ} \mathrm{C}$. The 
concentration of protein samples to be electrophoresed synchronized by means of dilution..

Soluble protein profiles of bacterial cells visualized by SDS-PAGE. The gel used is discontinuous gel consisting of $5 \%$ stacking gel and 10\% resolving gel. The concentration of protein samples were loaded into the wells, the concentration was adjusted to $35 \mu \mathrm{g} / \mathrm{ml}$. Marker protein used is a product of Fermentas (Fermentas life sciences). Gels were stained with a solution of $1 \%$ coomassie brilliant blue destaining then performed with a mixed solution of methanol and glacial acetic acid and distilled water at a ratio of 5:1:4, until the protein bands clearly visible.

The molecular weight of each protein band in the gel of each strain of bacteria is determined by measuring the molecular mobility of proteins in polyacrylamide gel based protein molecular weight standard curve of reference. Reference (marker) protein that known molecular weight, electrophoresed along with the tested bacterial protein, and mobility (retention factor) was calculated using the formula:

$R f=\frac{\text { Distance movement protein bands from a starting place }}{\text { Distance movement tracker color from a starting place }}$

The standard curve of reference protein molecular weight was made to the linear regression equation of the relationship between the retention factor (X-axis) and the logarithm of the molecular weight (Y-axis).

\section{Data analysis of protein profiles}

Data were analyzed using MVSP Plus software-version 3.1 (Kovach, 2007) to determine the similarity between strains. Similarity value is determined using simple matching coefficient (SSM), the grouping is done by algorithms UPGMA (Unweighted Pair Group Method with Arithmetic Averages) (Sneath \& Sokal, 1973). The results of the analysis were presented as dendogram using the Corel Draw X5. Dendogram produced subsequently used as a basis to determine the similarity between strains. Identification of indigenous cellulose-producing acetic acid strain conducted by comparing the similarity index between tested strains with reference strains.

\section{Results and Discussion}

Dendrogram constructed based on 54 phenotypic characters to identify all strains in the species level by numerical systematic analysis showed that cellulose-producing acetic acid bacteria strains in this study more closely the similarity to the reference strain G. xylinus BTCC 769 compared to the other two strains of reference namely $G$. hansenii NBRC $14820^{\mathrm{T}}$ and G. liquefaciens NBRC $12388^{\mathrm{T}}$ (data not shown). The whole soluble protein profiles of cellulose-producing acetic acid bacteria strains along with reference strains visualized by SDS-PAGE method is shown in Figure 1. Representative diagram shown in Figure 2.

Construction the representative diagram of dissolved whole cell protein profiles done using the Corel Draw X5, then the data on the protein bands representative diagram estimated molecular weight is determined by molecular weight protein markers (Table 1). Data molecular weight protein bands in Table 1 were then analyzed by numerical systematic method based on the Simple Matching Coefficient (SSM) and the algorithm Unweighted Pair Group Method with Arithmetic Average Encryption (UPGMA) was then constructed in the form of dendrogram (Figure 3).

Analysis of whole cell protein extracts against four strains of indigenous celluloseproducing acetic acid bacteria showed differences between the tested strains. Four tested and two reference strains showed 12 protein bands with three predominant protein bands i.e protein with a molecular weight of $102.015 \mathrm{kDa} ; 81.750 \mathrm{kDa}$ and $69.168 \mathrm{kDa}$.

Among the 12 occurring protein bands, there are six protein bands shared by all strains i.e protein band with a molecular weight of $102.015 \mathrm{kDa} ; 81.750 \mathrm{kDa} ; 69.168 \mathrm{kDa} ; 49.515$ $\mathrm{kDa} ; 3.681 \mathrm{kDa}$ and $19.099 \mathrm{kDa}$. Reference strain G. xylinus BTCC 769 had eleven protein bands so that there was one protein band that was not owned by the $132.182 \mathrm{kDa}$. Strain of ANG 29 had nine protein bands so that there 


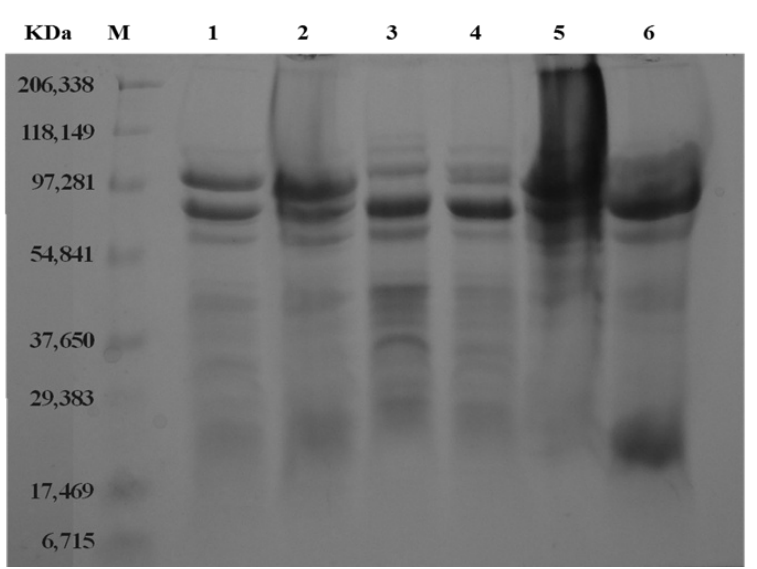

Figure 1. Profile of total soluble protein from selected acetic acid bacteria and reference strains using SDS PAGE. Lane 1 (G. xylinus BTCC 769), lane 2 (ANG 29 isolates), lane 3 (isolate ANG 32), lane 4 (isolate SAL 53), lane 5 (isolate KRE 65), lane 6 (G. hansenii NBRC 14820 ), M (marker molecular weight proteins).

were three protein bands did not appear, namely $132.182 \mathrm{kDa} ; 39.845 \mathrm{kDa}$ and 34.858 $\mathrm{kDa}$. Strain of ANG 32 showed twelve protein bands, so that to become strain with highest number of protein bands. SAL 53 strain showed eleven protein bands together with a reference strain G. xylinus BTCC 769, so just less one protein band that is $132.182 \mathrm{kDa}$. KRE 65 strain showed nine protein bands and there are 3 protein bands did not appear, namely $132.182 \mathrm{kDa} ; 34.858 \mathrm{kDa}$ and 30.623 $\mathrm{kDa}$. The other reference strain $\mathrm{G}$. hansenii NBRC $1420^{\mathrm{T}}$ has the least amount of protein

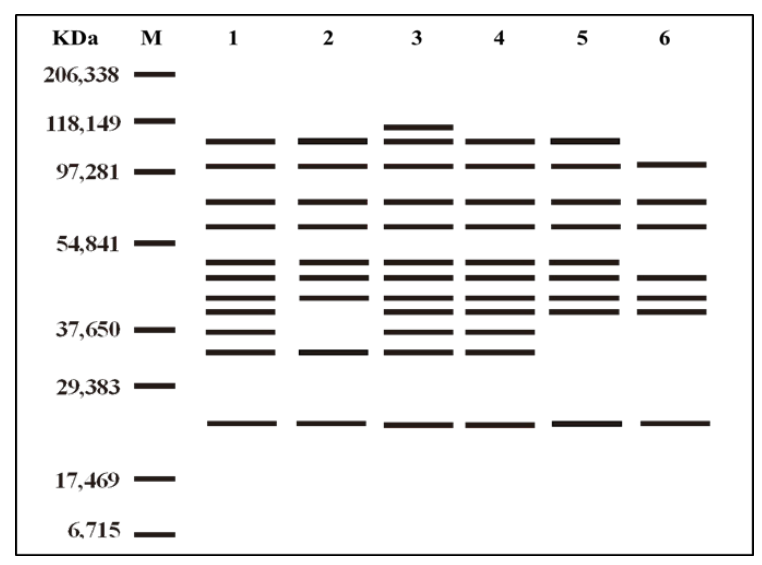

Figure 2. Representative diagram of total protein SDSPAGE of selected acetic acid bacteria and reference strains. Lane 1 (G. xylinus BTCC 769), lane 2 (ANG 29 isolates), lane 3 (isolate ANG 32), lane 4 (isolate SAL 53), lane 5 (isolate KRE 65), lane 6 (G. hansenii NBRC 14820 ), M (marker molecular weight proteins).

bands among all tested strains because there are only 7 protein bands and there were 5 protein bands that were not owned by the 132.182 kDa; $120.573 \mathrm{kDa} ; 54.967 \mathrm{kDa} ; 34.858$ $\mathrm{kDa}$ and $30.623 \mathrm{kDa}$.

Based on the dendrogram from numerical analysis of whole cellular protein profiles four cellulose-producing acetic acid bacteria strains and two reference strains (Figure 3), indicating that the strains separated into three distinct clusters that joined at the similarity value of $68.3 \%$. The first cluster consists of three strains namely G. xylinus

Table 1. The molecular weight of protein from selected acetic acid bacteria and members of the genus Gluconacetobacter reference strains.

\begin{tabular}{|c|c|c|c|c|c|c|c|}
\hline No. & $\begin{array}{l}\text { Molecular weight } \\
\text { of protein bands } \\
\text { (KDa) }\end{array}$ & 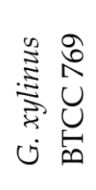 & $\begin{array}{l}2 \\
0 \\
z\end{array}$ & $\begin{array}{l}N \\
0 \\
u \\
Z\end{array}$ & 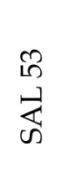 & $\begin{array}{l}\qquad 8 \\
\sqrt[10]{2} \\
\underline{v}\end{array}$ & 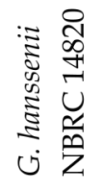 \\
\hline 1. & 132,182 & - & - & + & - & - & - \\
\hline 2. & 120,573 & + & + & + & + & + & - \\
\hline 3. & 102,015 & + & + & + & + & + & + \\
\hline 4. & 81,750 & + & + & + & + & + & + \\
\hline 5. & 69,168 & + & + & + & + & + & + \\
\hline 6. & 54,967 & + & + & + & + & + & - \\
\hline 7. & 49,515 & + & + & + & + & + & + \\
\hline 8. & 43,681 & + & + & + & + & + & + \\
\hline 9. & 39,845 & + & - & + & + & + & + \\
\hline 10. & 34,858 & + & - & + & + & - & - \\
\hline 11. & 30,623 & + & + & + & + & - & - \\
\hline 12. & 19,099 & + & + & + & + & + & + \\
\hline
\end{tabular}




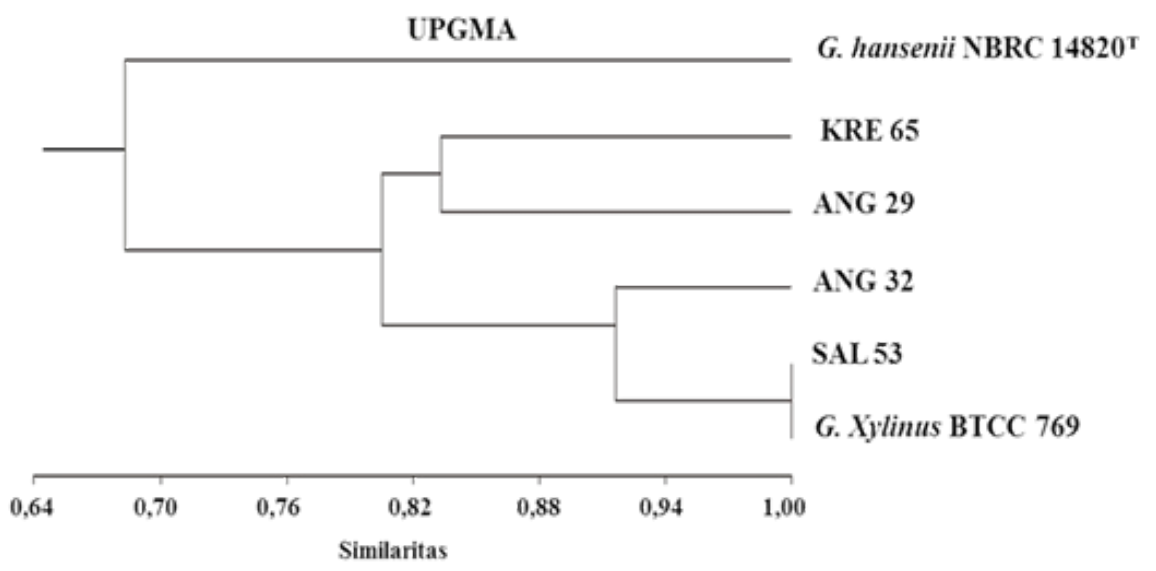

Figure 3. The molecular weight of protein from selected acetic acid bacteria and members of the genus Gluconacetobacter reference strains.

BTCC 769, SAL 53 and ANG 32 that joined in a cluster with a similarity value of $91.7 \%$. Reference strain G. xylinus BTCC 769 and SAL 53 joined in a cluster with a similarity value of $100 \%$. The third member of this first cluster different from each other because they do not have one specific band with the same molecular weight was132.182 kDa (Table 1). This protein band owned only by isolates ANG 32 .

The second cluster consisting of two isolates namely ANG 29 and KRE 65 who joined with the similarity index of $83.3 \%$. The first and second cluster joins with similarity index value of $80.6 \%$. The second cluster members do not have two specific protein bands with the same molecular weight 132.182 and $34.858 \mathrm{kDa}$ and a different specific protein with molecular weight of $39.845 \mathrm{kDa}$ in the strain ANG 29 and $30.623 \mathrm{kDa}$ in strain KRE 65 . The third cluster consists of a reference strain G. hansenii NBRC 14820 were joined by the other cluster with similarity index of $68.3 \%$.

Based on total soluble cellular protein profiles can beexplained that the four celluloseproducing acetic acid bacteria showed higher similarity profile to the reference strain $G$. xylinus BTCC 769 than G. hansenii NBRC $14820^{\mathrm{T}}$. Strain SAL 53 have the highest level of similarity with the reference strain G. xylinus BTCC 769 with $100 \%$ similarity index. Strain ANG 32 has lower similarity with similarity index of $91.7 \%$. Strains ANG 29 and KRE 65 have the lowest similarity to G. xylinus BTCC 769 with a similarity index of $80.6 \%$. Fourth strains have low similarity with the reference strain G. hansenii NBRC 14820 with an index of similarity $68.3 \%$. Dendrogram constructed based on the chemical character cellular protein profiles showed that the cellular protein profiles quite well used to differentiate strains of acetic acid bacteria based on an index of similarity. Higher similarity of strains ANG 29, ANG 32, SAL 53 and KRE 65 to the reference strain G. xylinus BTCC 769 in good agreement with numerical analysis based on phenotypic characters. This reinforces the notion that the four strains of indigenous cellulose producing acetic acid bacteria in this research were members of the species G. xylinus.

These results were consistent with previous research using SDS-PAGE techniques to distinguish the whole cellular protein profiles in the group of lactic acid bacteria (Ghazi et al., 2009). However, a different result was demonstrated when the technique is applied to a group of bacteria of the genus Salmonella (Aksakal, 2010). Ghazi et al. (2009) states that the result of analysis of whole cellular protein profiles can be used to strengthen, complement and confirm the results of the phenotypic identification of lactic acid bacteria group. SDS-PAGE method can generate a complex pattern of protein bands and stable so that it can be used to interpret and compare the protein profiles of samples tested strain with the reference strain. Meanwhile, Aksakal (2010) concluded that whole cellular protein profiles cannot be used to distinguish between strains in the genus Salmonella. This study showed that the whole cellular protein profiles by SDS-PAGE 
technique can be used as one method to identify the new strains of acetic acid bacteria, although it is not necessarily suitable to the other group of bacteria. Congruence of differences between bacterial isolates between the total cellular protein profile and the phenotypic character of selected celluloseproducing acetic acid bacterial isolates with the reference strains indicate that at least, the protein profile can be used as a support for the identification of cellulose-producing acetic acid bacteria based on phenotypic characters.

\section{Conclusions}

Whole cell protein profiles can be used to differentiate cellulose-producing acetic acid bacteria strains based on index of similarity, thus can be used as one method for identifying cellulose-producing acetic acid bacteria strains to supplement the results of the phenotypically identification.

\section{References}

Aksakal, A. 2010. Analysis of whole cell protein profiles of Salmonella serovars isolated from chicken, turkey and sheep faeces by SDS-PAGE. Vet. Med., 55 (6), 259-263.

Bradford, M.M. 1976. A rapid and sensitive method for quantification of microgram quantities of protein utilizing the principle of protein-dye binding. Anal. Biochem., 72, 248-254.

De Ley, J., Swings, J., and Gossele F. 1984. Genus I. Acetobacter beijerinck 1898, 215AL. In Bergey's Manual of Systematic Bacteriology, vol. 1, pp. 268-274. (N. R. Krieg \& J. G. Holt, eds.). Baltimore: Williams \& Wilkins.

Dellaglio, F., Cleenwerck, I., Felis, G.E., Engelbeen, K., Janssens, D., and Marzotto, M. 2005. Description of Gluconacetobacter swingsii sp. nov. \& Gluconacetobacter rhaeticus sp. nov., isolated from Italian apple fruit. Int. J. Syst. Evol. Microbiol., 55(6), 2365-2370.

Dicks, L.M.T., van Vuuren, H.J.J., and Dellaglio, F. 1990. Taxonomy of Leuconostoc species, particularly Leuconostoc oenos, as revealed by numerical analysis of total soluble cell protein patterns, DNA base compositions, and DNA-DNA hybridizations. Int. J. Syst. Evol. Microbiol., 40, 83-91.

Ghazi, F., Henni, D.E., Benmechernene, Z., and Kihal, M. 2009. Phenotipic and whole cell protein analysis by SDSPAGE for identification of dominant lactic acid bacteria isolated from Algerian raw milk. World J. Dairy Food Sci., 4(1), 78-87.

Greenberg, D.E., Porcella, F.S., Stock, F., Wong, A., Conville, P.S., Murray, P.R., Holl, S.M., and Zelazny, A.M. 2006. Granulibacter bethesdensis gen. nov., sp. nov., a distinctive pathogenic acetic acid bacterium in the family Acetobacteraceae. Int. J. Syst. Evol. Microbiol., 56, 2609-2616.

Hanmoungjai, W., Chukeatirote, E., Pathomaree, W., Yamada, Y., and Lumyoung, S. 2007. Identification of acidotolerant acetic acid bacteria isolated from Thailand source. Res. J. Microbiol., 2 (2), 194-197.

Holt. G., Kreig, N.R., Sneath, P.H.A., Stanley, J.T., and Williams, S.T. 1994. Bergeys manual of determinative bacteriology. $9^{\text {th }}$ Edition. Baltimore: William \& Wilkins.

Hwan, Y.S., Lee, O.S., Lee, I.S., Kim, H.S., Yu, T.S., and Jeong, Y.J. 2004. Gluconacetobacter persimmonis sp. nov., isolated from Korean traditional persimmon vinegar. J. Microbiol. Biotechnol., 14, 276-283.

Jin, J., Kim, S.Y., Jin, Q., Eom, H., and Han, N.S. 2008. Diversity analysis of lactic acid bacteria in takju, Korean rice wine. J. Microbiol. Biotechnol., 18, 1678-1682.

Jojima, Y., Mihara, Y., Suzuki, S., Yokozeki, K., Yamanaka, S., and Fudou, R. 2004. Saccharibacter floricola gen. nov., sp. Nov., a novel osmophilic acetic acid bacterium isolated from polen. Int. J. Syst. Evol. Microbiol., 54, 2263-2267.

Jonas, R., and Farah, L.F. 1998. Production \& application of microbial cellulose. Polym. Degrad. Stab., 59, 101-106.

Kadere, T.T., Miyamoto, T., Oniang, R.K., 
Kutima, P.M., and Njoroge, S.M. 2008. Isolation and identification of the genera Acetobacter and Gluconobacter in coconut toddy (mnazi). African J. Biotechnol., 7 (16), 2963-2971.

Kim, T.W., Jung, S.H., Lee, J.Y., Choi, S.K., Park, S.H., Jo, J.S., and Kim, H.Y. 2003. Identification of lactic acid bacteria in kimchi using SDS-PAGE profiles of whole cell proteins. J. Microbiol. Biotechnol., 13, 119-124.

Klemm, D., Schumann, D., Udhardt, U., and Marsch, S. 2001. Bacterial synthesized cellulose-artificial blood vessels for microsurgery. Prog. Polym. Sci., 26, 1561-1603.

Kovach Computing Services. 2007. Multivariate statistical package plus version 3.1: User's Manual. UK: Pentraeth.

Lisdiyanti, P., Kawasaki, H., Seki, T., Yamada, Y., Uchimura, T., and Komagata, K. 2001. Identification of Acetobacter strains isolated from Indonesian sources, and proposals of Acetobacter syzygii sp. nov., Acetobacter cibinongensis sp. nov. and Acetobacter orientalis sp. nov. J. Gen. Appl. Microbiol., 47, 119131.

Muramatsu, Y., Yukphan, P., Takahashi, M., Kaneyasu, M., Malimas, T., Potacharoen, W., Yamada, Y., Nakagawa, Y., Tanticharoen, M., and Suzuki, K. 2009. $16 \mathrm{~S}$ rRNA gene sequences analysis of acetic acid bacteria isolated from Thailand. Microbiol. Cult. Coll., 25(1), 13-20.

Park, J.K., Jung, J.Y., and Park, Y.H. 2003. Cellulose production by Gluconacetobacter hansenii in a medium containing ethanol. Biotechnol. Lett., 25, 2055-2059.

Pot, B., Hertel, C., Ludwig, W., Descheemaeker, P., Kersters, K., and Schleifer, K.H. 1993. Identification and classification of Lactobacillus acidophilus, L. gasseri, and L. johnsonii strains by SDS-PAGE and rRNA-targeted oligonucleotide probe hybridization. J. Gen. Microbiol., 139, 513-517.

Sanchez, I., Sese, S., and Palop, L. 2003. Identification of lactic acid bacteria from spontaneous fermentation of 'Almagro' eggplants by SDS-PAGE whole cell protein fingerprinting. Int. J. Food Microbiol., 82, 181-189.

Scopes, R.K. 1987. Protein purification. Principles and practice. $2^{\text {nd }}$ ed. New York: Springer Verlag.

Sievers, M., Ludwig, W., and Teuber, M. 1994. Phylogenetic positioning of Acetobacter, Gluconobacter, Rhodopila and Acidophilum species as a branch of acidophilic bacteria in the a-subclass of Proteobacteria based on 165 rDNA sequences. Syst. Appl. Microbiol., 17, 189-196.

Sneath, P.H.A, and Sokal, R.R. 1973. Numerical taxonomy: the principles and practice of numerical classification. San Francisco: Freeman.

Son, H.J, Heo, M.S., Kim, Y.G., and Lee, S.J. 2001. Optimization of fermentation conditions for the production of bacterial cellulose by a newly isolated Acetobacter sp. A9 in shaking cultures. Biotechnol. Appl. Biochem., 33, 1-5.

Swissa, M., Aloni, Y., Weinhouse, H., and Benziman, M. 1980. Intermediary step in Acetobacter xylinum cellulose synthesis studies with whole cells and cell free preparation of the wild type and a celluloses mutant. J. Bacteriol., 143, 1142-1150. 